Volume 15, No. 2, Juli 2018

\title{
PENGETAHUAN DAN SIKAP MENCUCI TANGAN YANG BENAR MENURUT KESEHATAN
}

\author{
Sherly E S, Darmiah, Imam Santoso, Erminawati \\ Poltekkes Kemenkes Banjarmasin Jurusan Kesehatan Lingkungan Banjarbaru \\ Jl. H. Mistar Cokrokusumo No. 1A Banjarbaru \\ e-mail: darmiah0708@gmail.com
}

\begin{abstract}
Knowledge and Attitude of Proper Handwashing According to Health. Getting used to wash hands with soap (CTPS) is the same as teaching children and all family members to live healthy early has an important role in relation to disease prevention, such as diseases of worms and can serve to reduce microorganisms in the hands. The purpose of this research was to know the application of PHBS about the knowledge and attitude of proper hand washing according to health in Elementary School Regency of Hulu Sungai Selatan. The research design was descriptive, cross sectional research design. Data coection used questionnaires that were filled directly by students. The population of the study were 110 students, the sampling using Proportional Random Sampling technique was obtained by 51 students. The results showed enough knowledge categories as many as 20 students (39.22\%), less as many as 31 students (60.78\%). Good attitude category as many as 39 students (76.47\%), quite as many as 7 students $(13,72 \%)$ and attitude which still less as much as 5 student (9.80\%). The conclusion of the research of students' knowledge about proper hand washing according to health, has enough category, even more that still less, while student attitude has been included good category. It is advisable to make efforts to increase the knowledge through the extension method of Clean and Healthy Behavior (PHBS), especially hand washing properly according to the health routinely by school and related institution such as local health center.
\end{abstract}

Keywords: Knowledge; Attitude; Proper Handwashing; Primary school

\begin{abstract}
Abstrak: Pengetahuan dan Sikap Mencuci Tangan Yang Benar Menurut Kesehatan. Membiasakan Cuci Tangan Pakai Sabun (CTPS) sama dengan mengajarkan anak dan seluruh anggota keluarga hidup sehat sejak dini mempunyai peranan penting dalam kaitannya dengan pencegahan penyakit, seperti penyakit kecacingan dan dapat berfungsi untuk mengurangi mikroorganisme di tangan. Tujuan penelitian mengetahui penerapan PHBS tentang pengetahuan dan sikap mencuci tangan yang benar menurut kesehatan di Sekolah Dasar Kabupaten Hulu Sungai Selatan. Rancangan penelitian bersifat deskriptif, desain penelitian cross sectional. Pengumpulan data menggunakan instrumen kuesioner yang diisi secara langsung oleh siswa. Populasi penelitian sebanyak 110 siswa, pengambian sampel menggunakan teknik Proportional Random Sampling didapat sebanyak 51 siswa. Hasil penelitian menunjukkan kategori pengetahuan cukup sebanyak 20 siswa (39,22\%), kurang sebanyak 31 siswa $(60,78 \%)$. Kategori sikap baik sebanyak 39 siswa $(76,47 \%)$, cukup sebanyak 7 siswa $(13,72 \%)$ dan kurang sebanyak 5 siswa $(9,80 \%)$. Kesimpulan penelitian pengetahuan siswa tentang mencuci tangan yang benar menurut kesehatan, mempunyai kategori cukup, bahkan lebih banyak yang masih kurang, sedangkan sikap siswa sudah termasuk kategori baik. Disarankan melakukan upaya peningkatan wawasan dan pengetahuan melalui metode penyuluhan tentang Perilaku Hidup Bersih dan Sehat (PHBS) khususnya mencuci tangan yang baik dan benar menurut kesehatan secara rutin baik oleh pihak sekolah maupun instansi terkait seperti puskesmas setempat.
\end{abstract}

Kata kunci: Pengetahuan; Sikap; Mencuci Tangan Yang Benar; Sekolah Dasar 


\section{PENDAHULUAN}

Perilaku Hidup Bersih dan Sehat (PHBS) merupakan cerminan pola hidup keluarga yang senantiasa memperhatikan dan menjaga kesehatan seluruh anggota keluarga. Mencegah lebih baik dari pada mengobati, prinsip kesehatan inilah yang menjadi dasar dari pelaksanaan PHBS. Kegiatan PHBS tidak dapat terlaksana apabila tidak ada kesadaran dari seluruh anggota keluarga itu sendiri. PHBS harus diterapkan sedini mungkin agar menjadi kebiasaan positif dalam memelihara kesehatan[1]. Pelaksanaan program PHBS dikelompokkan menjadi 5 tatanan yaitu di sekolah, di Rumah Tangga, di Institusi Kesehatan, di tempat-tempat umum dan di Tempat Kerja[2]. Dari ke lima program tersebut, PHBS di sekolah merupakan tatanan awal untuk kemajuan Bangsa dan Negara. Tatanan sekolah merupakan salah satu ruang lingkup promosi kesehatan yang sangat efektif, karena anak sekolah merupakan sasaran yang mudah dijangkau sebab terorganisasi dengan baik serta merupakan kelompok umur yang peka dan mudah untuk dibimbing, diarahkan, dan ditanamkan kebiasaan-kebiasaan baik ${ }^{[3]}$. Kebiasaan cuci tangan sebelum makan, memakai air dan sabun mempunyai peranan penting dalam kaitannya dengan pencegahan infeksi kecacingan, karena dengan mencuci tangan dengan air dan sabun lebih efektif menghilangkan kotoran dan debu secara mekanis dari permukaan kulit dan mengurangi jumlah mikroorganisme penyebab penyakit seperti virus, bakteri dan parasit seperti telur cacing yang menempel pada permukaan kulit, kuku dan jari-jari kedua tangan[1].

Kedua tangan kita sangat penting untuk membantu menyelesaikan berbagai pekerjaan. Makan dan minum sangat membutuhkan kerja dari tangan. Jika tangan kotor, maka tubuh sangat berisiko terhadap masuknya mikroorganisme. Cuci tangan dapat berfungsi untuk menghilangkan/mengurangi mikroorganisme yang menempel di tangan. Cuci tangan harus dilakukan dengan menggunakan air bersih dan sabun. Air yang tidak bersih banyak mengandung kuman dan bakteri penyebab penyakit.
Bila digunakan, kuman berpindah ke tangan. Pada saat makan, kuman dengan cepat masuk ke dalam tubuh, yang bisa menimbulkan penyakit. Sabun dapat membersihkan kotoran dan membunuh kuman, karena tanpa sabun, maka kotoran dan kuman masih tertinggal di tangan ${ }^{[1]}$.

Pengetahuan merupakan hasil tahu dan terjadi setelah orang melakukan penginderaan terhadap suatu objek tertentu. Pengetahuan merupakan domain yang sangat penting dalam membentuk tindakan seseorang. Sikap merupakan reaksi atau respon yang masih tertutup dari seseorang terhadap stimulus atau objek. Sikap secara nyata menunjukkan konotasi adanya kesesuaian reaksi terhadap stimulus sosial[2]. Anak usia sekolah memiliki kesadaran yang kurang mengenai perilaku cuci tangan pakai sabun yang baik dan benar. Biasanya anak usia sekolah hanya mengerti bahwa cuci tangan yang penting tangannya basah saja, padahal cuci tangan saja atau cuci tangan tidak menggunakan sabun masih meninggalkan kuman atau kurang bersih sehingga belum bisa di katakana cuci tangan yang baik dan benar. Sehingga dibutuhkan peran pelaku kesehatan untuk memberikan informasi kepada masyarakat termasuk anak usia sekolah mengenai perilaku cuci tangan pakai sabun agar dapat mewujudkan masyarakat berperilaku hidup bersih dan sehat ${ }^{[1]}$. Berdasarkan analisis kecenderungan secara rerata nasional, terdapat peningkatan proporsi masyarakat berperilaku cuci tangan secara benar pada tahun 2013 yaitu 47,0\% dibandingkan tahun 2007 yaitu $23,2 \%$. Peningkatan tertinggi proporsi masyarakat berperilaku cuci tangan benar terjadi di Bangka Belitung dengan besar kenaikan $35,0 \%(20,6 \%$ pada tahun 2007 menjadi $55,6 \%$ pada 2013 ) [4].

SDN Bayanan 2 terletak di Jalan Bintara, Desa Bayanan Kecamatan Daha Selatan Kabupaten Hulu Sungai Selatan, merupakan SDN milik Pemerintah yang di bangun tahun 1992 mempunyai 5 orang guru PNS dan 3 orang guru honor, 110 murid. Kawasan tersebut terletak dipinggir sungai Daha Selatan sehingga terlihat kurang bersih dibandingkan dengan 
Sekolah Dasar yang tidak berada dipinggir sungai. Kebanyakan perekonomian orang tua murid termasuk dalam perekonomian yang rendah yang mana kebanyakan pekerjaannya adalah sebagai petani. Ratarata pendidikan dari orang tua hanya sebatas SD, oleh karena itu orang tua kurang memberikan pengetahuan kepada anak tentang pentingnya perilaku hidup bersih dan sehat salah satunya tentang cuci tangan dengan air mengalir dan memakai sabun. Penduduk didesa Bayanan, Daha Selatan menggunakan air sungai untuk keperluan sehari hari misalnya mandi, Buang Air Besar (BAB), Buang Air Kecil (BAK), mencuci baju, memasak dan untuk air minum. Dari sini kita dapat melihat bahwa didesa Bayanan Daha Selatan sangat rentan terkena penyakit, khususnya penyakit diare.

Di Kalimantan Selatan kasus Diare mengalami peningkatan dan penurunan pada tahun 2013 sampai tahun 2015. Namun, meningkat secara drastis pada tahun 2015 dibanding 3 tahun terakhir. Salah satu kota di Kalimantan Selatan yang tinggi kasus Diare adalah Hulu Sungai Selatan menduduki urutan ke 2 di tahun 2015[5].

Data Dinas Kesehatan, Kabupaten Hulu Sungai Selatan, pada tahun 2013 desa Bayanan menduduki urutan pertama kasus diare, terdapat 875 kasus diare pada anak usia $>5$ tahun, terdiri dari 309 anak laki-laki dan 566 anak perempuan. Pada tahun 2014 kasus mengalami penurunan sebanyak 463 kasus diare, 213 anak lakilaki dan 250 anak perempuan. Sedangkan pada tahun 2015 terjadi peningkatan kasus diare pada anak usia $>5$ tahun yaitu sebanyak 719 kasus diare yang mana dari jumlah tersebut sebanyak 293 anak lakilaki dan 426 anak perempuan[6].

\section{BAHAN DAN CARA PENELITIAN}

Desain penelitian secara observasional, yaitu sebuah bentuk penelitian yang berdasarkan pada penglihatan dan pen- catatan suatu keadaan atau fenomena yang terjadi pada objek penelitian[7]. Penelitian dibatasi pada penerapan PHBS tentang pengetahuan dan sikap mencuci tangan yang benar menurut kesehatan. Populasi merupakan keseluruhan sumber data yang diperlukan dalam suatu penelitian. Populasi dapat berupa manusia, hewan, tumbuhan dan lain-lain[8]. Jumah populasi dalam penelitian ini sebanyak 110 siswa. Pengambilan sampel menggunakan metode Simple Random Sampling, dengan teknik Proportional Random Sampling yaitu pengambilan sampel secara proporsi dilakukan dengan mengambil subyek dari setiap strata atau wilayah ditentukan seimbang dengan banyaknya subyek dan masing-masing strata atau wilayah [9]. Didapatkan jumlah sampel sebanyak 51 siswa. Jumlah pembagian sampel masingmasing kelas menurut ${ }^{[10]}$ : kelas $\mathrm{I}=4$ siswa, kelas II = 7 siswa, kelas III =13 siswa, kelas $\mathrm{IV}=7$ siswa, kelas $\mathrm{V}=9$ siswa dan kelas VI = 11 siswa.

Pengumpulan data menggunakan instrumen berupa kuesioner tertutup, yang diisi langsung oleh siswa dengan memberikan tanda cheklist pada jawaban yang dianggap benar. Penilaian pernyataan positif (favourable) jika responden menjawab benar mendapatkan skor 1 dan jika salah mendapatkan skor 0. Pernyataan negatif (unfavourable) jika responden menjawab dengan benar mendapatkan skor 0 dan jika salah mendapatkan skor 1 . Pernyataan disusun berdasarkan kisi-kisi dari sumber teori tentang cuci tangan pakai sabun. Pernyataan terdiri dari pernyataan positif (favourable) dan pernyataan negative (unfavourable) dengan pilihan jawaban benar dan salah $^{[11] .}$

\section{HASIL PENELITIAN DAN PEMBAHASAN}

Karakteristik Siswa dengan kategori jenis kelamin dan umur siswa dapat diihat pada tabel 1 berikut: 
Tabel 1. Kategori Jenis Kelamin dan Umur Siswa

\begin{tabular}{cccc}
\hline No & Kategori Jenis Kelamin & Frekuensi & $(\%)$ \\
\hline 1 & Laki-laki & 26 & 50,98 \\
2 & Perempuan & 25 & 49,02 \\
& Total & 51 & 100 \\
& Kategori Umur & & \\
1 & 7 Tahun & 4 & 7,86 \\
2 & 8 - 11 Tahun & 36 & 70,58 \\
3 & 12 Tahun & 11 & 21,56 \\
& Total & 51 & 100 \\
\hline
\end{tabular}

Tabel 1 menunjukkan bahwa distribusi jenis kelamin hampir sama antara laki-laki dan perempuan, frekuensi umur yang paling banyak yaitu pada kategori antara umur 8 tahun sampai 11 tahun $(70,58 \%)$.
Hasil tabel silang kategori kelas dengan pengetahuan Siswa di Sekolah Dasar Tahun 2016 dapat diihat pada tabel 2 berikut:

Tabel 2. Tabel Silang Kelas dengan Pengetahuan siswa

\begin{tabular}{cccccccc}
\hline & \multicolumn{7}{c}{ Pengetahuan } \\
No & Kelas & \multicolumn{2}{c}{ Cukup } & \multicolumn{2}{c}{ Kurang } & $\sum$ & $\%$ \\
& & $\mathrm{n}$ & $\%$ & $\mathrm{n}$ & $\%$ & & \\
\hline 1. & I & 0 & 0 & 4 & 100 & 4 & 100 \\
2. & II & 3 & 42,85 & 4 & 57,14 & 7 & 100 \\
3. & III & 3 & 23 & 10 & 76,92 & 13 & 100 \\
4. & IV & 4 & 57,14 & 3 & 42,85 & 7 & 100 \\
5. & V & 7 & 77,77 & 2 & 22,22 & 9 & 100 \\
6. & VI & 3 & 27,27 & 8 & 72,72 & 11 & 100 \\
\hline \multicolumn{2}{l}{ Total } & 20 & 39,21 & 31 & 60,78 & 51 & 100 \\
\hline
\end{tabular}

Tabel 2 menunjukkan bahwa siswa kelas $\mathrm{V}$ mempunyai kategori pengetahuan cukup sebesar 77,77\%. Angka tersebut menunjukkan besarnya pengetahuan cukup di bandingkan dengan kelas lainnya, terutama bagi kelas VI yang seharusnya mempunyai pengetahuan yang lebih baik di bandingkan dengan kelas dibawahnya. Pengetahuan merupakan hasil dari tahu, dan ini terjadi setelah orang melakukan penginderaan terhadap suatu objek tertentu. Penginderaan terjadi melalui panca indra manusia, yakni indra penglihatan, pendengaran, rasa dan raba. Sebagian besar pengetahuan manusia diperoleh melalui mata dan telinga ${ }^{[2]}$. Pengetahuan yang dimiliki seseorang tidaklah sama, melainkan bertingkattingkat dimana hal tersebut tergantung pada upaya untuk mempelajarinya lebih dalam. pengetahuan siswa di Sekolah Dasar tentang mencuci tangan yang benar menurut kesehatan dari 51 orang siswa yang diteliti, sebanyak 20 orang siswa $(39,21 \%)$ dengan kategori pengetahuan cukup, dan sebanyak 31 orang siswa $(60,78 \%)$ dengan kategori pengetahuan kurang. Berdasarkan hasil di atas, pengetahuan siswa di Sekolah Dasar tentang mencuci tangan yang benar menurut kesehatan dengan kategori pengetahuan menduduki nilai terbesar sebanyak 31 orang $(62,75 \%)$. Artinya pengetahuan siswa tentang mencuci tangan yang benar menurut kesehatan di Sekolah Dasar dapat dikatakan kurang.

Siswa yang mempunyai pengetahuan kurang paling banyak terdapat pada siswa yang duduk di kelas III dan VI. Semakin tinggi tingkat pendidikan tidak mempengaruhi dengan bertambahnya ilmu pengetahuan. Oleh karena itu, siswa yang duduk di kelas IV dan V pengetahuannya lebih baik dibandingkan kelas diatasnya. Pengetahuan yang lebih baik kemungkinan dapat berkaitan dengan antara lain: a). Sosial ekonomi, Status 
ekonomi akan mempengaruhi pengetahuan siswa, seperti tersedianya suatu fasilitas cuci tangan di rumah mereka yang menjadikan suatu kebiasaan hidup bersih dan sehat terutama mencuci tangan yang benar menurut kesehatan. Status ekonomi yang lebih baik akan mudah tercukupi dibanding dengan orang yang memiliki status ekonomi rendah, semakin tinggi status ekonomi seseorang semakin mudah dalam mendapatkan pengetahuan, sehingga menjadikan hidup yang berkualitas. diperlukan, sehingga status ekonomi ini akan mempengaruhi pengetahuan seseorang. b). Lingkungan, lingkungan sangat berpengaruh terhadap proses masuknya pengetahuan. Seperti siswa yang berada pada lingkungan orang berpengetahuan tinggi maka akan menambah tingkat pengetahuan siswa tersebut dan c). Pengalaman, Pengalaman siswa tentang berbagai hal biasanya diperoleh dari lingkungan kehidupan dalam proses pengembangan misalnya sering mengikuti organisasi. Pembiasaan yang di lakukan di sekolah mempunyai dampak yang lebih baik dalam kehidupan keseharian, terutama siswa yang sudah terbiasa melakukan cuci tangan di rumah akan lebih baik dibandingkan dengan yang tidak biasa dilakukan di rumah, artinya kebiasaan itulah pengalaman yang dilakukan oleh siswa.

Hasil kuesioner pengetahuan siswa di Sekolah Dasar yang dikategorikan menjadi baik, cukup dan kurang dapat dilihat pada tabel 3.

Tabel 3. Distribusi Frekuensi Menurut Pengetahuan Siswa

\begin{tabular}{cccc}
\hline No & Kategori & Frekuensi & $(\%)$ \\
\hline 1. & Baik & 0 & 0 \\
2. & Cukup & 20 & 39,22 \\
3. & Kurang & 31 & 60,78 \\
& Total & 51 & 100 \\
\hline
\end{tabular}

Tabel 3 menunjukkan pengetahuan siswa tentang mencuci tangan yang benar menurut kesehatan berdasarkan kategori yang ditetapkan oleh Suharsimi Arikunto[9], sebanyak 20 siswa $(39,22 \%)$ pada kategori cukup, dan 31 siswa $(60,78 \%)$ pada kategori kurang.

Hasil kuesioner pernyataan mengenai sikap siswa dalam mencuci tangan yang benar menurut kesehatan di Sekolah Dasar dapat dilihat pada tabel 4.

Tabel 4. Distribusi Frekuensi Menurut Sikap Siswa Sekolah Dasar

\begin{tabular}{llccc}
\hline No & & Kategori & Frekuensi & $(\%)$ \\
\hline 1. & Baik & & 39 & 76,47 \\
2. & Cukup & & 7 & 13,72 \\
3. & Kurang & & 5 & 9,81 \\
& & Total & 51 & 100 \\
\hline
\end{tabular}

Berdasarkan data pada tabel 4, Pernyataan sikap siswa tentang mencuci tangan yang benar menurut kesehatan berdasarkan kategori yang ditetapkan oleh Suharsimi Arikunto[9], sebanyak 39 siswa $(76,47 \%)$ memiliki sikap pada kategori baik, sebanyak 7 siswa $(13,72 \%)$ memiliki sikap pada kategori cukup dan 5 siswa $(9,80 \%)$ memiliki sikap pada kategori kurang. Pernyataan sikap dari 51 orang siswa yang diteliti paling banyak pada kategori baik, hal ini menunujukkan bahwa sikap siswa tentang mencuci tangan yang benar menurut kesehatan di Sekolah Dasar dapat dinyatakan sudah baik. Sikap adalah reaksi atau respon yang masih tertutup dari seseorang terhadap suatu stimulus atau objek. Manisfestasi sikap atau tidak dapat langsung dilihat, tetapi hanya dapat ditafsirkan terlebih dahulu dari perilaku yang tertutup[2]. Artinya siswa di Sekolah Dasar menyatakan sudah mau untuk melakukan 
perubahan sikap tentang mencuci tangan yang benar menurut kesahatan.

Fasilitas sekolah yang menunjang untuk mencuci tangan dengan benar menurut kesehatan akan mempunyai dampak yang positif pada sikap siswa untuk bersikap lebih baik tentang mencuci tangan yang benar menurut kesehatan. Hal ini sesuai dengan komponen sikap yang dikemukakan oleh Notoatmodjo[12] yaitu kepercayaan (keyakinan) artinya, bagaimana keyakinan dan pendapat atau pemikiran seseorang terhadap objek. Komponen sikap yang selanjutnya adalah kehidupan emosional atau evaluasi terhadap suatu objek artinya bagaimana penilaian (terkandung di dalamnya faktor emosi) orang tersebut terhadap objek. Dan komponen yang terakhir adalah kecenderungan untuk bertindak artinya sikap yang mendahului tindakan atau berperilaku terbuka.

Masalah kesehatan di negara-negara berkembang pada prinsipnya menyangkut dua aspek, aspek fisik dan aspek non fisik. Aspek fisik menyangkut Aspek Nonperilaku (misalnya lingkungannya). Aspek nonfisik menyangkut perilaku kesehatan. Berdasarkan dua masalah kesehatan tersebut, pendekatan dalam memecahkan masalah kesehatan dibagi menjadi dua pendekatan fisik dan pendekatan nonfisik (melalui peningkatan perilaku). Kedua pendekatan tersebut harus sejalan dalam memecahkan masalah kesehatan dan masing-masing memiliki kontribusi yang sama. Pemberian fasilitas fisik tanpa diikuti oleh peningkatan pengetahuan dan kesadaran masyarakat memberikan hasil yang jauh dari harapan[13]. Berdasarkan keadaan di Sekolah Dasar, aspek nonfisik misalnya lingkungan dapat berupa melengkapi fasilitas cuci tangan untuk siswa dan meningkatkan promosi kesehatan berupa menambahkan posterposter yang berisi pesan tentang mencuci tangan yang benar menurut kesehatan.

Berdasarkan keadaan di Sekolah Dasar, aspek nonfisik menyangkut perilaku kesehatan dapat berupa siswa yang memiliki pengetahuan kurang tentang mencuci tangan yang benar menurut kesehatan di Sekolah Dasar harus menambah wawasan dan pengetahuan tentang mencuci tangan yang benar dan siswa yang memiliki sikap baik tentang mencuci tangan yang benar menurut kesehatan di Sekolah Dasar untuk dapat melakukan hal nyata dalam membiasakan berperilaku hidup bersih dan sehat dengan cara rutin melakukan cuci tangan dengan benar menggunakan sabun.

\section{KESIMPULAN DAN SARAN}

Penerapan PHBS tentang pengetahuan dan sikap siswa Sekolah Dasar tentang mencuci tangan yang benar menurut kesehatan dari 51 orang siswa yang diteliti, untuk kategori pengetahuan yang baik $0 \%$, sebanyak 39,22\% kategori pengetahuan siswa cukup, dan 60,78\% pengetahuan kurang. Sedangkan hasil tentang sikap, sebanyak $76,47 \%$ sikap siswa baik, sebanyak 13,72\% memiliki sikap kategori cukup dan 9,80\% memiliki sikap masih termasuk kategori kurang. Saran yang dapat disampaikan untuk meningkatkan pengetahuan dan dapat mempertahankan sikap siswa yang sudah baik dalam penerapan PHBS dapat diupayakan dengan memberikan rewards atau penghargaan bagi siswa yang telah membiasakan cuci tangan dengan benar, melengkapi fasilitas cuci tangan seperti sabun untuk cuci tangan dan menambahkan poster-poster yang berisi pesan tentang mencuci tangan yang benar menurut kesehatan. Serta memberikan penyuluhan tentang Perilaku Hidup Bersih dan Sehat (PHBS) khususnya mencuci tangan yang benar menurut kesehatan yang diaksanakan secara rutin baik oleh pihak sekoah maupun kerjasama dengan instansi terkait seperti Puskesmas setempat dalam kegiatan Puskesmas Keliling.

\section{KEPUSTAKAAN}

1. Proverawati, R. 2012. Perilaku Hidup Bersih dan Sehat. Yogyakarta: Nuha Medika.

2. Notoatmodjo, S. 2007. Kesehatan Masyarakat Ilmu dan Seni. Jakarta: PT. Rineka Cipta.

3. Lucie, S. 2005. Teknik Penyuluhan dan Pemberdayaan Masyarakat. Bogor. Penerbit Ghalia Indonesia. 
4. Propil Kesehatan Indonesia tahun 2013. Kementerian Kesehatan Repubik Indonesia.

5. Dinas Kesehatan Provinsi Kalimantan Selatan. 2015. Data Penyakit Diare Tahun 2015. Provinsi Kalimantan Selatan.

6. Dinas Kesehatan Hulu Sungai Selatan.2015. Data Penyakit Diare Tahun 2015. Kabupaten Huu Sungai Selatan (HSS).

7. Notoatmodjo, S. 2010. Metodologi Penelitian Kesehatan.Jakarta: PT, Rineka Cipta
8. Saryono. 2008. Metodologi Penelitian Kesehatan. Yogyakarta: Mitra Cendekia Press.

9. Arikunto, S. 2006. Prosedur Penelitian Suatu Pendekatan Praktik. Jakarta: PT. Rineka Cipta.

10. Sugiyono, 2010, Statistik Untuk Penelitian. Bandung: Alfabeta.

11. Santoso, I. 2013. Manajemen Data. Yogyakarta: Gosyen Publishing.

12. Notoatmodjo, S. 2003. Pendidikan dan Perilaku Kesehatan. Jakarta: PT. Rineka Cipta.

13. Maulana.D.J.H. 2009. Promosi Kesehatan. Jakarta : EGC 
